\title{
PENGARUH PENAGIHAN PAJAK DENGAN SURAT TEGURAN DAN SURAT PAKSA TERHADAP KEPATUHAN WAJIB PAJAK DI LINGKUNGAN KANWIL DJP JAWA TENGAH I DAN JAWA TENGAH II
}

\begin{abstract}
The purpose of this research is to determine the effect of tax addiction with admission letter and enforcement letter toward tax payer compliance. The method that be used in this research is multiple linier regression which test using SPSS Program In this research, the sample is taken from admission letters and enforcement letter that issued by tax office in the Directorate General of Taxation Central Java I and Central Java II Territory during period 2010 and 2011. The method for choosing the sample is nonprobability, choosing sample based on simplycity Based on the result of the research, shows that the result of hypothesis partially (t-test) get the significancy variable score admission letter and enforcement letter is 0,003 and 0,001 smaller than 0,05. So its proved that admission letter and enforcement letter have significant influence toward tax payer compliance. Determination coefficient shows 0,324 or 32,4\% means 32,4\% tax payer compliance is influenced by admission letter and enforcement letter.
\end{abstract}

Key words: tax addiction, admissin letter, enforcement letter, tax payer compliance.

\section{PENDAHULUAN}

Dalam kurun 4 tahun terakhir sektor pajak makin menunjukkan dominasinya sebagai penyumbang utama sumber pendapatan negara. Bahkan pada tahun 2012 dari total pendapatan negara sebesar Rp. 1.292.048,7 triliun, Rp. 976.898,8 trilun berasal dari pajak. Hal ini berarti sektor pajak menyumbang lebih dari $70 \%$ (tujuh puluh persen) dari total pendapatan negara. Kendati demikian, kinerja Direktorat Jenderal Pajak belum dapat sepenuhnya dibilang berhasil, karena terhitung sejak tahun 2009, target penerimaan pajak tidak pernah tercapai.

Selama ini pemerintah menuding lesunya kondisi perekonomi global sebagai salah satu penyebab gagalnya Direktorat Jenderal Pajak mencapai target penerimaaan pajak. Alasan yang tidak sepenuhnya salah, namun ketika hal ini diperburuk dengan jumlah tunggakan pajak yang selalu bertambah dari tahun ke tahun (kecuali pada tahun 2012), patut diduga bahwa ada masalah dengan kepatuhan wajib pajak.Menjadi pertanyaan berbagai pihak apakah Ditjen pajak telah melakukan law enforcement kepada para penunggak pajak untuk mengatasi hal ini dan apabila telah dilakukan bagaimana dengan efektifitasnya.

Timbulnya tunggakan pajak tak bisa dilepaskan dari sistem pemungutan pajak yang saat ini dianut oleh Indonesia yaitu sistem self assessmentdimana dalam sistem ini wajib pajak diberikan kepercayaan penuh untuk menghitung, menyetor dan melaporkan sendiri jumlah pajak yang terutang, sehingga kepatuhan wajib pajak dalam menghitung, menyetor dan melaporkan jumlah pajak terutangnya secara benar sesuai dengan ketentuan undang undang perpajakan adalah kunci dalam keberhasilan pencapaian target penerimaan pajak. Besarnya kepercayaan yang diberikan kepada wajib pajak seringkali menimbulkan risiko wajib pajak tidak 
menjalankan kewajiban perpajakannya dengan benar, baik disebabkan karena kelalaian, kesengajaan maupun karena ketidaktahuan wajib pajak.Untuk meminimalisir risiko ini pemerintah dalam hal ini Direktorat Jenderal Pajak sesuai dengan undang undang perpajakan, berwenang untuk melakukan penelitian dan pemeriksaan pajak untuk menguji kepatuhan wajib pajak dalam pemenuhan kewajiban perpajakannnya.

Tindakan penelitian yang dilakukan oleh Direktorat Jenderal Pajak akan menghasilkan produk hukum berupa Surat Tagihan Pajak (STP). STP adalah surat untuk melakukan tagihan pajak dan/atau sanksi administrasi berupa bunga dan/atau denda. Salah satu hal yang sering menyebabkan terbitnya STP adalah Wajib Pajak terlambat menyampaikan SPT. Sedangkan tindakan pemeriksaan pajak akan menghasilkan produk hukum berupa Surat Ketetapan Pajak. Apabila berdasarkan hasil pemeriksaan, produk hukum yang dihasilkan adalah Surat Ketetapan Pajak Kurang Bayar (SKPKB) dan Surat Ketetapan Pajak Kurang Bayar Tambahan (SKPKBT) dimana jumlah pajak yang masih harus dibayarbertambah, dan sampai dengan jangka waktu yang ditetapkan berdasarkan peraturan perundang-undangan perpajakan tidak dibayar oleh penanggung pajak maka Direktorat Jenderal Pajak dapat melakukan penagihan pajak.Tindakan penagihan juga berlaku untuk STP apabila sampai dengan jangka waktu yang ditetapkan penanggung pajak tidak melunasi utangnya.

Ketentuan mengenai tindakan penagihan pajak telah diatur dalam Undang Undang nomor 19Tahun 1997 sebagaimana telah diubah terakhir dengan Undang Undang nomor 19 Tahun 2000 tentang Penagihan Pajak dengan Surat Paksa. Undang undang inilah yang menjadi payung hukum bagi serangkaian proses tindakan penagihan yang dilakukan oleh Direktorat Jenderal Pajak agar Wajib Pajak segera melunasi utang pajaknya. Adanya undang undang yang menjadi dasar hukum penagihan dan peningkatan tindakan penagihan oleh Direktorat Jenderal Pajak ternyata tidak serta mampu mengurangi jumlah piutang pajak, bahkan dari tahun ke tahun jumlah piutang pajak cenderung mengalami kenaikan. Hal ini membuat efektifitas tindakan penagihan dipertanyakan dalam upaya pencairan piutang pajak.

Beberapa penelitian pernah dilakukan untuk menguji pengaruh tindakan penagihan terhadap pembayaran tunggakan pajak. Mecca Liona (2010) dalam penelitiannya menyimpulkan bahwa surat paksa dan surat sita berpengaruh terhadap penerimaan pencairan tunggakan pajak, hasil serupa juga ditunjukkan oleh Mayang Wijoyanti (2010) yang memperoleh kesimpulan bahwa surat paksa berpengaruh terhadap tingkat kepatuhan wajib pajak.

Berbeda dengan hasil penelitian diatas, dalam penelitiannya Nana Edriana Erwis (2012) menyimpulkan hal yang berbeda, bahwa Surat Teguran dan Surat Paksa tidak efektif dalam meningkatkan penerimaan pajak. Hasil yang tak jauh berbeda juga ditunjukkan oleh Affan Marhaendi $(2009,12)$ yang menyatakan bahwa tindakan penagihan aktif berpengaruh negatif dan tidak signifikan terhadap pencairan piutang pajak. Variabel penagihan aktif dalam penelitian tersebut termasuk didalamnya adalah penyampaian surat teguran dan surat paksa

Berdasarkan uraian diatas penulis tertarik untuk melakukan pengulangan atau replikasi penelitian yang dilakukan oleh Nana Edriana Erwis (2012) dengan melakukan penelitian terhadap surat teguran dan surat paksa namun dengan ruang lingkup dan tempat yang berbeda dimana Nana Edriana Erwis melakukan penelitian pada 1 (satu ) unit kerja yaitu KPP Pratama Makasar Selatan dengan periode tahun 2010 dan 2011

Jurnal Akuntansi Indonesia 
sedangkan penulis akan melakukan penelitian pada unit kerja Kantor Pelayanan Pajak di lingkungan Kantor Wilayah DJP Jawa Tengah I dan Jawa Tengah II yaitu sejumlah 29 ( dua puluh sembilan) kantor pelayanan pajak dengan lingkup tahun 2010 dan 2011. Dalam penelitian ini penulis mengambil judul "Pengaruh Penagihan Pajak dengan Surat Teguran dan Surat Paksa Terhadap Kepatuhan Wajib Pajak di Lingkungan Kantor Wilayah DJP Jawa Tengah I dan Jawa Tengah II"

\section{KAJIAN PUSTAKA DAN PENGEMBANGAN HIPOTESIS}

\section{Pengertian Penagihan Pajak}

Undang-undang Nomor 19 Tahun 1997 sebagaimana diubah terakhir dengan UU Nomor 19 tahun 2000 tentang Penagihan Pajak dengan Surat Paksa, pasal 1 menyebutkan pengertian penagihan sebagai serangkaian tindakan agar penanggung pajak melunasi utang pajak dan biaya penagihan pajak dengan menegur atau memperingatkan, melaksanakan penagihan seketika sekaligus, memberitahukan Surat Paksa, mengusulkan pecegahan, melaksanakan penyitaan, melaksanakan penyanderaan, menjual barang yang telah disita. Sedangkan pengertian penagihan menurut Moeljo Hadi, SH (1999:11) adalah serangkaian tindakan dari aparatur Direktorat Jenderal Pajak, berhubung Wajib Pajak tidak melunasi sebagian atau seluruh kewajiban perpajakan yang terutang menurut undang-undang perpajakan yang berlaku.

\section{Penagihan Pajak dengan Surat Teguran}

Penyampaian surat teguran merupakan awal pelaksanaan tindakan penagihan oleh fiskus untuk memperingatkan Wajib Pajak yang tidak melunasi utang pajaknya sesuai dengan keputusan penetapan (STP, SKPKB, SKPKBT) sampai dengan saat jatuh tempo. Surat teguran adalah surat yang diterbitkan oleh pejabat untuk menegur atau memperingatkan Wajib Pajak untuk melunasi utang pajaknya. Surat teguran dikeluarkan apabila utang pajak yang tercantum dalam STP, SKPKB atau SKPKBT tidak dilunasi sampai melewati waktu hari dari batas waktu jatuh tempo 1 bulan sejak tanggal diterbitkannya.

\section{Penagihan Pajak dengan Surat Surat Paksa}

Menurut pasal 8 ayat (1) UU PPSP Surat Paksa diterbitkan apabila:

1. Penanggung pajak tidak melunasi utang pajak sampai dengan tanggal jatuh tempo pembayaran dan kepadanya telah diterbitkan Surat Teguran atau Surat Peringatan atau surat lain yang sejenis.

2. Terhadap penanggung pajak telah dilaksanakan penagihan pajak seketika dan sekaligus.

3. Penanggung pajak tidak memenuhi ketentuan sebagaimana tercantum dalam keputusan persetujuan angsuran atau penundaan pembayaran pajak.

\section{Jangka Waktu Penagihan Pajak}

Menurut Keputusan Menteri Keuangan Nomor 561/KMK.04/2000 tentang Tata Cara Pelaksanaan Penagihan Seketika dan Sekaligus dan Penagihan Pajak dengan Surat Paksa menguraikan hal-hal yang berkaitan dengan penagihan pajak yaitu sebagai berikut: 
1. Tindakan pelaksanaan penagihan diawali dengan penerbitan Surat Teguran setelah 7 hari jatuh tempo surat pembayaran ketetapan pajak. Surat Teguran tidak diterbitkan terhadap penanggung pajak yang telah disetujui untuk mengangsur atau menunda pembayaran pajaknya.

2. Apabila jumlah utang pajak yang harus dilunasi tidak dibayar oleh penunggang pajak dalam jangka waktu 21 hari sejak diterbitkannya surat teguran, maka akan diterbitkan surat paksa.

3. Apabila jumlah utang pajak yang harus dilunasi penanggung pajak telah lewat waktu $2 \times 24$ jam setelah surat paksa diberitahukan, maka akan diterbitkan Surat Perintah Melaksanakan Penyitaan (SPMP).

4. Apabila utang pajak dan biaya penagihan yang masih harus dilunasi oleh penanggung pajak setelah lewat waktu 14 hari sejak tanggal pelaksanaan penyitaan, maka akan dilaksanakan pengumuman lelang.

5. Apabila utang pajak dan biaya penagihan yang masih harus dilunasi oleh penanggung pajak setelah lewat waktu 14 hari sejak tanggal pengumuman lelang. akan segera dilakukan penjualan barang sitaan penanggung pajak melalui kantor lelang.

\section{Kepatuhan Wajib Pajak}

Menurut Zain (2003:31) kepatuhan pajak adalah suatu iklim kepatuhan dan kesadaran pemenuhan kewajiban perpajakan yang tercermin dalam situasi dimana Wajib Pajak paham dan berusaha untuk memahami semua ketentuan peraturan perundang-undangan perpajakan, mengisi formulir pajak dengan lengkap dan jelas, menghitung jumlah pajak yang terutang dengan benar dan membayar pajak tepat pada waktunya.

Pengertian kepatuhan pajak menurut Nurmantu (2005:14) yaitu: “kepatuhan perpajakan adalah suatu keadaan dimana Wajib Pajak memenuhi semua kewajiban perpajakannya". Dari pengertian-pengertian tersebut maka dapat disimpulkan bahwa kepatuhan Wajib Pajak adalah suatu sikap taat dari Wajib Pajak untuk melaksanakan semua kewajiban perpajakannya sesuai dengan aturan aturan yang berlaku. Ada 2 macam kepatuhan, yaitu kepatuhan formal dan kepatuhan material:

1. Kepatuhan formal adalah suatu keadaan dimana Wajib Pajak memenuhi kewajiban secara formal sesuai dengan ketentuan dalam Undang-undang perpajakan.

2. Kepatuhan Material adalah suatu keadaan dimana wajib pajak secara substantive atau hakikatnya memenuhi semua ketentuan material perpajakan, yakni sesuai isi undang undang

Penagihan pajak adalah salah satu wewenang yang diamanatkan oleh undang undang perpajakan kepada Direktorat Jenderal Pajak. Tujuan penagihan pajak adalah agar Wajib Pajak atau Penanggung Pajak melunasi utang pajak dan biaya penagihan. Pelunasan utang pajak yang dilakukan oleh Wajib Pajak atau Penanggung Pajak adalah suatu bentuk kepatuhan dari Wajib Pajak itu sendiri.Agar tujuan penagihan tersebut tercapai, maka diperlukan serangkaian tindakan yang dapat diambil oleh jurusita mulai dari tindakan penerbitan surat teguran, penyampaian surat paksa, penyampaian surat perintah melakukan penyitaan, pelaksanaan penyitaan, penjualan barang hasil penyitaan sampai dengan tindakan pencegahan bepergian ke luar negeri dan penyanderaan. Adapun hipotesis dalam penelitian ini adalah sebagai berikut:

$\mathrm{H}_{1} \quad$ : Terdapat pengaruh yang signifikan antara penagihan pajak dengan surat teguran terhadap kepatuhan Wajib Pajak di lingkungan Kanwil DJP Jawa Tengah I dan Jawa Tengah II.

50

Jurnal Akuntansi Indonesia

Vol. 3 No. 1 Januari 2014 
$\mathrm{H}_{2} \quad$ : Terdapat pengaruh yang signifikan antara penagihan pajak dengan surat paksa terhadap kepatuhan Wajib Pajak di Lingkungan Kanwil DJP Jawa Tengah I dan Jawa Tengah II.

\section{METODE PENELITIAN}

\section{Objek Penelitian}

Objek yang dipilih oleh peneliti adalah kantor pelayanan pajak di lingkungan Kanwil DJP Jawa Tengah I dan II. Dalam penelitian ini, peneliti meneliti variabel kepatuhan wajib pajak yang merupakan variabel dependen serta surat teguran dan surat paksa sebagai variabel dependennnya

\section{Populasi Dan Sampel}

Populasi dalam penelitian ini adalah Kantor Pelayanan Pajak di seluruh Indonesia yang melakukan tindakan penagihan aktif berupa penyampaian surat Teguran dan Surat Paksa kepada wajib pajak yang memiliki utang pajak pada tahun 2010 s.d 2011.

Metode pemilihan sampel yang digunakan adalah metode pemilihan sampel nonprobabilitas yaitu pemilihan sampel berdasarkan kemudahan.Metode ini memilih sampel dari elemen populasi yang datanya mudah untuk diperoleh peneliti.

Sampel yang diambil penulis dalam penelitian ini adalah data pencairan tunggakan pajak dan laporan tindakan penagihan pajak pada Kantor Pelayanan Pajak di lingkungan Kantor Wilayah Direktorat Jenderal Pajak Jawa Tengah I dan Jawa Tengah II periode tahun 2010 dan2011

\section{Definisi Operasional Variabel}

Definisi operasional adalah definisi yang diberikan bagi variabel dengan cara memberikan arti sehingga dapat memberikan gambaran tentang bagaimana variabel tersebut dapat diukur

Ada 3 definisi operasional yang digunakan dalam penelitian ini yaitu sebagai berikut

a. Surat Teguran

Surat teguran adalah surat yang diterbitkan oleh pejabat untuk menegur atau memperingatkan Wajib Pajak untuk melunasi utang pajaknya.

b. Surat Paksa

Surat Paksa adalah surat perintah untuk segera membayar utang pajak dan biaya penagihan pajak yang disampaikan oleh jurusita pajak negara, apabila utang pajak tersebut tidak dilunasi setelah 21 hari dari tanggal surat teguran dikeluarkan...

c. Kepatuhan Wajib Pajak

Kepatuhan Wajib Pajak adalah kesadaran wajib pajak dalam melunasi pajak terutang.Wajib Pajak dalam hal ini adalah wajib pajak bebas yang memperoleh penghasilan sendiri atau dari pekerjaan bebas. 


\section{Pengukuran Variabel}

Dalam penelitian ini pengukuran variabel yang digunakan yaitu:

a. Variabel bebas atau variabel independen

Variabel bebas dalam penelitian ini adalah surat teguran dan surat paksa. Variabel surat teguran diukur dari jumlah surat teguran yang dikeluarkan oleh masing masing Kantor Pelayanan Pajak di lingkungan Kantor Wilayah DJP Jawa Tengah I dan Jawa Tengah II. Begitupun dengan variabel surat paksa juga diukur dengan cara sama yaitu dari jumlah surat paksa yang dikeluarkanmasing masing Kantor Pelayanan Pajak

b. Variabel terikat atau variabel dependen

Variabel terikat dalam penelitian ini adalah kepatuhan wajib pajak. Kepatuhan wajib pajak diukur berdasarkan persentasejumlah surat teguran dan surat paksa yang dilunasi dari seluruh jumlah seluruh surat teguran dan surat paksa yang diterbitkan.).Satuan pengukuran variabel ini adalah persen. Perhitungannya menggunakan rumus sebagai berikut :

ST yang dibayar (lembar) + SP yang dibayar(lembar) $\times 100 \%$

Jumlah ST yang diterbitkan (lembar) + SP yang diterbitkan (lembar)

\section{Teknik Analisis dan Uji Hipotesis}

\section{Teknik Analisis}

Untuk mengetahui pengaruh variable independen terhadap variable dependen digunakan alat analisis regresi berganda.Dengan sebelumnya diuji dari asumsi klasik berupa normalitas data, autokorelasi, heteroskedastisitas dan multikolinearitas.

\section{Uji Hipotesis}

Pengujian hipotesis yang digunakan dalam penelitian ini yaitu dengan melakukan uji t. Uji ini digunakan untuk mengetahui apakah variabel independen $(\mathrm{X})$ berpengaruh signifikan terhadap variabel $(\mathrm{Y})$

\section{Uji Koefisien Determinasi}

Untuk mengetahui presentase besarnya variasi yang diturunkan oleh variabel $X$,maka dilakukan perhitungan koefisien determinasi dengan rumus :

$$
K D=r^{2} \cdot 100 \%
$$

\section{HASIL DAN PEMBAHASAN}

\section{Model Persamaan Regresi}

Model persamaan yang diajukan dalam penelitian ini telah memenuhi persyaratan asumsi klasik sehingga model persamaan dalam penelitian ini sudah dianggap baik.Hasil persamaan regresi diolah dengan menggunakan SPSS versi 21. 
Berdasarkan tabel persamaan regresi, dapat dibuat persamaan regresi sebagai berikut :

$$
Y=21,963+0.005 X_{1}+0,020 X_{2}+e
$$

Persamaan regresi di atas, dapat dijelaskan sebagai berikut :

a. Nilai koefisien regresi surat teguran, sebesar 0,005 , bernilai positif, artinya apabila surat teguran meningkat 1 persen, maka kepatuhan wajib pajak akan meningkat sebesar 0,005 persen.

b. Nilai koefisien regresi surat paksa sebesar 0,020, bernilai positif, artinya apabila surat paksa meningkat sebesar 1 persen, maka nilai perusahaan akan meningkat sebesar 0,020 persen.

\section{Pengujian Hipotesis (Uji t)}

Terdapat pengaruh yang signifikan antara penagihan pajak dengan surat teguran terhadap kepatuhan wajib pajak di lingkungan Kanwil DJP Jawa Tengah I dan Jawa Tengah II.

Pengujian Hipotesis 1 mengenai pengaruh penagihan pajak dengan surat paksa terhadap kepatuhan wajib pajak diperoleh nilai t hitung sebesar 3,088 lebih besar dari t tabel sebesar 1,673 dan probabilitasnya adalah 0,003 atau lebih kecil dari 0,05 sehingga $\mathrm{H}_{0}$ ditolak dan Hipotesis 1 diterima

Terdapat pengaruh yang signifikan antara penagihan pajak dengan surat paksa terhadap kepatuhan wajib pajak di lingkungan Kanwil DJP Jawa Tengah I dan Jawa Tengah II

Pengujian hipotesis 2diperoleh nilai t hitung sebesar 3,633 lebih besar dari t tabel sebesar 1,673 dan probabilitasnya adalah 0,001 atau lebih kecil dari 0,05 sehingga $\mathrm{H}_{0}$ ditolak dan Hipotesis 2 diterima

\section{Koefisien Determinasi $\left(\mathbf{R}^{2}\right)$}

Berdasarkan hasil pengujian koefisien determinasi, maka diperoleh hasil nilai koefisien determinasi (Adjusted R Square) sebesar 0,324. Hal ini menunjukkan bahwa 32,4\% variabel dependen kepatuhan wajib pajak ditentukan oleh variabel independen (surat teguran dan surat paksa) sedangkan sisanya dijelaskan oleh faktor-faktor lain diantaranya kesadaran membayar pajak, tingkat pelayanan terhadap wajib pajak, perlawanan wajib pajak, dan lain-lain.

\section{Pembahasan}

Hasil pengujian hipotesis baik secara parsial dengan uji t maupun secara simultandengan uji $F$ telah memberikan beberapa kesimpulan sebagai berikut:

\section{Pengaruh Penagihan Pajak dengan Surat Teguran Terhadap Kepatuhan Wajib Pajak}

Berdasarkan pengujian Uji t didapatkan hasil bahwa hipotesis 1 diterima. Hal ini sesuai dengan hasil penelitian Lia Nurbaiti (2011) yang menyimpulkan bahwa terdapat pengaruh yang signifikan antara Surat Teguran dan Surat Paksa terhadap pelunasan tunggakan wajib pajak sebesar 22,3\% atau dengan kata lain $77,7 \%$ pelunasan tunggakan wajib pajak ditentukan oleh faktor lain. Namun hasil tersebut bertentangan dengan hasil penelitian Nana Edriana Erwis (2012) yang menyatakan bahwa tidak terdapat pengaruh yang signifikan antara penagihan pajak dengan surat teguran terhadap penerimaan pajak. Dalam penelitian 
tersebut Nana Edriana Erwis (2012) menyebutkan bahwa alamat penunggak pajak yang tidak ditemukan adalah penyebab paling dominan tidak cairnya tunggakan pajak selain karena kesadaran yang memang rendah dari wajib pajak untuk membayar tunggakan pajak.

Tindakan pelunasan oleh wajib pajak adalah bentuk kepatuhan wajib pajak dalam melaksanakan undang undang perpajakan. Kantor Pelayanan Pajak yang menerbitkan surat teguran lebih banyak, maka kepatuhan wajib pajaknya cenderung lebih baik, akan tetapi apabila dilihat dari nilai koefisien regresi, pengaruh kepatuhan wajib pajak dari penerbitan surat teguran lebih kecil daripada pengaruh penerbitan surat paksa

Dari hasil diatas juga dapat dilihat bahwa dalam melaksanakan kewajiban perpajakannya wajib pajak lebih memiliki kesadaran melunasi utang pajaknya setelah mendapatkan surat teguran dari Kantor Pelayanan Pajak. Hal ini bisa disebabkan karena ketidaktahuan wajib pajak sebelum mendapat surat teguran ataupun karena kondisi keuangan wajib pajak yang sedang tidak memungkinkan.

\section{Pengaruh penagihan pajak dengan surat paksa terhadap kepatuhan wajib pajak}

Hasil pengujian Uji t juga menyatakan bahwa Hipotesis 2 diterima. Hal ini sesuai dengan penelitian Mayang Wijoyanti (2010) yang menyatakan bahwa penagihan pajak dengan surat paksa mempunyai pengaruh yang signifikan terhadap kepatuhan wajib pajak. Namunsekali lagi bertentangandengan hasil penelitian Nana Edriana Erwis (2012) yang menyatakan bahwa suratpaksamemberikan pengaruh yang kurang signifikan terhadap penerimaan pajak. Perbedaan pengambilan data sampel dimana dalam penelitian Nana Edriana Erwis hanya mengambil sampel dari satu KPP yaitu KPP Pratama Makassar Selatan disinyalir menjadi salah satu penyebab perbedaan kesimpulan ini terjadi, selain faktor faktor lain. Beberapa faktor yang mempengaruhi signifikansi surat paksa terhadap penerimaan piutang pajak namun tidak diuji dalam penelitian ini menurut N. Christanto Aji Cahyo (2010) antara lain:

a. Wajib pajak pindah alamat sehingga jurusita pajak tidak menjumpai wajib pajak

b. Wajib pajak menolak surat paksa

c. Jurusita mendapatkan perlawanan dari wajib pajak

d. Wajib pajak sedang mengajukan keberatan atau banding

\section{Kesimpulan}

Berdasarkan hasil penelitian yang telah dilakukan, maka dapat dibuat kesimpulan sebagai berikut :

Tindakan penagihan pajak dengan surat teguran secara individu berpengaruh positif dan signifikan terhadap kepatuhan wajib pajak. Ini membuktikan bahwa kesadaran wajib pajak dalam membayar pajak sangat ditentukan oleh penegakan peraturan di bidang perpajakan salah satunya adalah dengan melakukan tindakan penagihan aktif dengan surat teguran kepada para pengemplang pajak.

Surat paksa yang diterbitkan juga mempunyai pengaruh signifikan terhadap kepatuhan wajib, bahkan kontribusi terhadap kepatuhan wajib pajak lebih besar dibanding penerbitan surat teguran. Hal ini sekali lagi membuktikan bahwa tindakan pengawasan oleh Direktorat Jenderal Pajak dapat meningkatkan kepatuhan 
wajib pajak. Dengan catatan bahwa wajib pajak yang mendapatkan surat paksa tidak dalam keadaan bangkrut ataupun badan usaha yang sudah bubar serta keberadaannya tidak dapat ditemukan lagi, karena faktor inilah penyebab terbesar ketidaktertagihan tunggakan pajak selama ini. Tindakan penagihan pajak dengan surat teguran dan surat paksa secara bersama-sama mempunyai pengaruh yang signifikan terhadap kepatuhan wajib pajak

\section{Saran}

Berdasarkan hasil penelitian diatas, maka penulis mencoba memberikan beberapa saran sebagai berikut :

Direktorat Jenderal Pajak perlu meningkatkan kegiatan sosialisasi kepada wajib pajak mengenai hak dan kewajiban yang dimiliki wajib pajak sehingga tercipta masyarakat sadar dan peduli pajak, yang pada akhirnya dapat meningkatkan kepatuhan wajib pajak

Direktorat Jenderal Pajak perlu meningkatkan kualitas dan kuantitas Jurusita Pajak sebagai ujung tombak fungsi penagihan pajak, karena sudah terbukti bahwa tindakan penagihan aktif dapat meningkatkan kepatuhan wajib pajak Perbaikan sistem informasi penagihan pada jaringan intranet Direktorat Jenderal Pajak sehingga dapat menghasilkan informasi yang terintegrasi dan up to dateyang pada akhirnya dapat mendukung pelaksanaan kegiatan penagihan pajak

\section{DAFTAR PUSTAKA}

Brotodihardjo, R. Santoso. 2010. Pengantar Ilmu Hukum Pajak. Jakarta: Refika Aditama

Direktorat Jenderal Pajak. 2012. Pedoman Penagihan Pajak 2012. Jakarta: Direkotorat Pemeriksaan dan Penagihan.

Erwis, Nana Adriana. 2012. Efektivitas Penagihan Pajak Dengan Surat Paksa dan Surat Teguran Pada Kantor Pelayanan Pajak Pratama Makassar Selatan. Skripsi. Universitas Hasanuddin. Makassar

Gunadi. 2004. Bunga Rampai Pemeriksaan, Penyidikan dan Penagihan Pajak. Jakarta: PT. Multi Utama Indojasa Liona,Mecca.2010.Pengaruh Penagihan Pajak Dengan Surat Paksa dan Surat Sita Terhadap Penerimaan Pencairan Tunggakan Pajak Pada Kantor Pelayanan Pajak Pratama Jakarta Pasar Minggu.Skripsi.UPN "Veteran" Jakarta.

Mardiasmo. 2011. Perpajakan (Edisi revisi 2011). Yogyakarta: Penerbit Andi

Marhaendi, Affan. 2009. Pengaruh Penagihan Pajak Dengan Surat Paksa Dalam Usaha Mencairkan Tunggakan Pajak di KPP Pratama Jakarta Tamansari Satu. Skripsi. Universitas Gunadarma. Jakarta

Nurbaiti, Lia. 2011. Pengaruh Surat Teguran dan Surat Paksa Terhadap Penerimaan Pelunasan Tunggakan Pajak Wajib Pajak di Kantor Pelayanan Pajak Pratama Jakarta Cilandak.Skripsi. UPN “Veteran” Jakarta

Nurmantu, Syafri. 2003. Pengantar Perpajakan. Jakarta: Penerbit Granit

Peraturan Menteri Keuangan Nomor 201/PMK.03/2010 tentang perubahan atas PMK Nomor 62/PMK.03.2008 tentang Tata Cara Pelaksanaan Penagihan dengan Surat Paksa dan Pelaksanaan Penagihan Seketika dan Sekaligus. Kementerian Keuangan. Jakarta 
Sarwono, Jonathan. 2012. Metode Riset Skripsi Pendekatan Kuantitatif Menggunakan Prosedur SPSS. Jakarta: PT. Media Elex Komputindo.

Soemitro, Rochmat. 1996. Pengantar Singkat Hukum Pajak. Jakarta: PT Eresco.

Suandy, Early. 2005. Hukum Pajak. Jakarta: Salemba Empat

Surat Edaran Direktur Jenderal Pajak Nomor 29//PJ/2012 tentang Kebijakan Penagihan Pajak 2012. Direktorat Jenderal Pajak. Jakarta

Undang-Undang Republik Indonesia Nomor 19 Tahun 1997 Tentang Penagihan Pajak Dengan Surat Paksa. Pemerintah RI. Jakarta

Undang-Undang Republik Indonesia Nomor 19Tahun 2000Tentang Perubahan Atas Undang-Undang Republik Indonesia Nomor 19 Tahun 1997 Tentang Penagihan Pajak Dengan Surat Paksa. Pemerintah RI. Jakarta Undang-Undang Republik Indonesia Nomor 28Tahun 2007 Tentang Perubahan Keempat Atas Undang-Undang Nomor 6 Tahun 1983 Tentang Ketentuan Umum Dan Tata Cara Perpajakan. Pemerintah RI. Jakarta Waluyo, Cahyo. 2006. Perpajakan Indonesia Revisi. Jakarta: Salemba Empat.

Wijoyanti, Mayang. 2010. Pengaruh Penagihan Pajak Dengan Surat Paksa Terhadap Kepatuhan Wajib Pajak di Kantor Pelayanan Pajak Pratama Jakarta Mampang Prapatan. Skripsi. UPN “Veteran” Jakarta.

Zain, Mohammad. 2003. Manajemen Perpajakan. Jakarta: Salemba Empat.

Jurnal Akuntansi Indonesia 


\section{LAMPIRAN}

Gambar 1

KERANGKA PEMIKIRAN TEORITIS

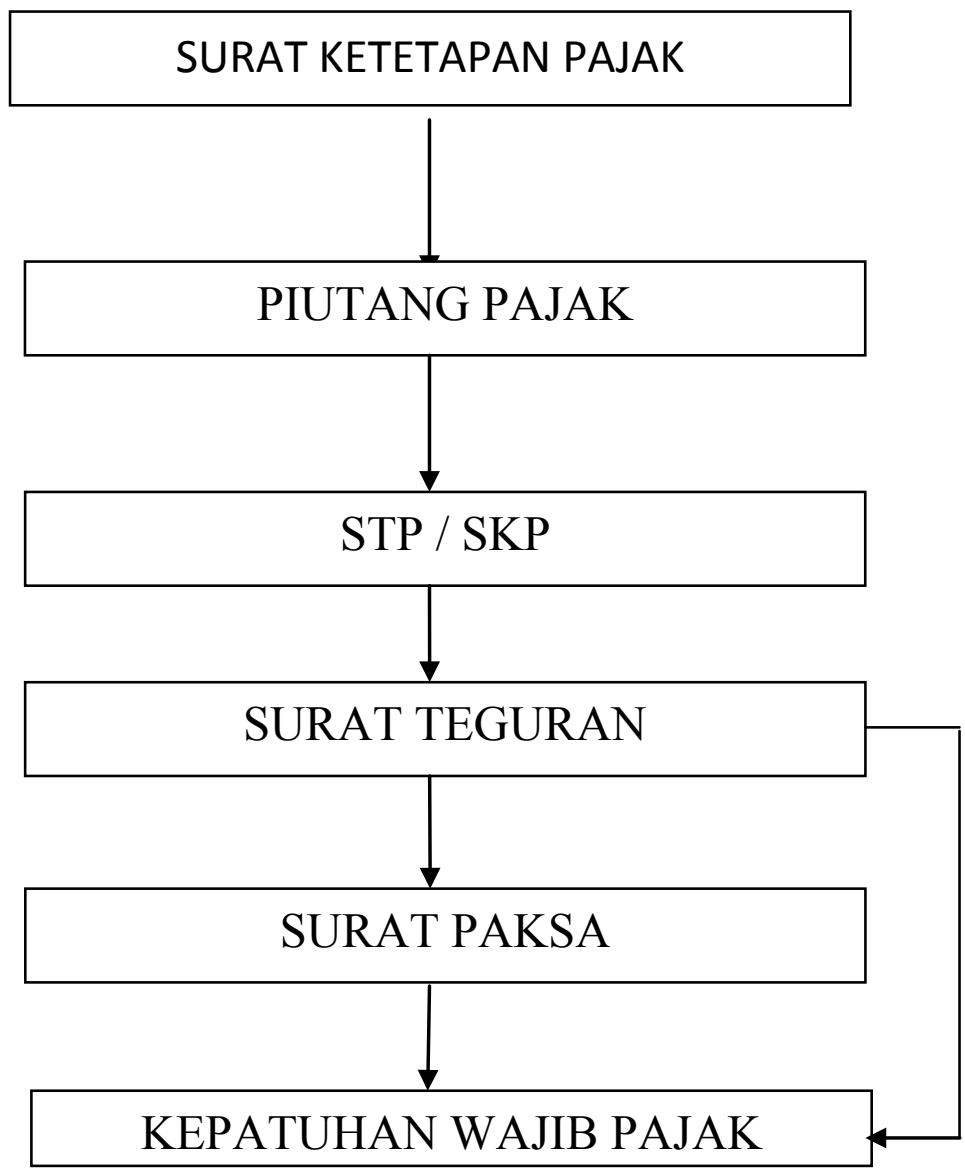

Tabel 1

Model Persamaan Regresi

Coefficients $^{\mathrm{a}}$

\begin{tabular}{|c|c|c|c|c|c|c|c|c|}
\hline & \multirow[t]{2}{*}{ Model } & \multicolumn{2}{|c|}{$\begin{array}{c}\text { Unstandardized } \\
\text { Coefficients }\end{array}$} & \multirow{2}{*}{$\begin{array}{c}\begin{array}{c}\text { Standardized } \\
\text { Coefficients }\end{array} \\
\text { Beta }\end{array}$} & \multirow[t]{2}{*}{$\mathrm{t}$} & \multirow[t]{2}{*}{ Sig. } & \multicolumn{2}{|c|}{ Collinearity Statistics } \\
\hline & & B & Std. Error & & & & Tolerance & VIF \\
\hline \multirow{3}{*}{1} & (Constant) & 21,963 & 3,012 & & 7,292 & ,000 & & \\
\hline & Teguran & ,005 & ,002 & ,347 & 3,088 & ,003 & 991 & 1,009 \\
\hline & Paksa & ,020 & ,006 & ,408 & 3,633 & ,001 & 991 & 1,009 \\
\hline
\end{tabular}

a. Dependent Variable: Kepatuhan

Sumber : data diolah menggunakan SPSS 
JURNAL AKUNTANSI INDONESIA

Tabel 2

Koefisien Determinasi $\left(\mathrm{R}^{2}\right)$

\begin{tabular}{cccccc}
\hline Model & $R$ & R Square & Adjusted R Square & $\begin{array}{c}\text { Std. Error of the } \\
\text { Estimate }\end{array}$ & Durbin-Watson \\
\hline 1 & $590^{\mathrm{a}}$ &, 348 &, 324 & 11,68686 & 1,901 \\
\hline
\end{tabular}

a. Predictors: (Constant), Paksa, Tegur

b. Dependent Variable: Kepatuhan

Jurnal Akuntansi Indonesia 